Volume 8

Number 1 Fall 2020 Symposium Edition Local

Citizens in a Global Age

Article 3

$12-29-2021$

\title{
Equality and Closure: The Paradox of Local Citizenship
}

Kenneth A. Stahl

Chapman University Fowler School of Law, kstahl@chapman.edu

Follow this and additional works at: https://scholarship.law.tamu.edu/journal-of-property-law

Part of the Law and Society Commons, Property Law and Real Estate Commons, and the Public Law and Legal Theory Commons

\section{Recommended Citation}

Kenneth A. Stahl, Equality and Closure: The Paradox of Local Citizenship, 8 Tex. A\&M J. Prop. L. 29 (2021).

Available at: https://doi.org/10.37419/JPL.V8.11.3

This Symposia Article is brought to you for free and open access by Texas A\&M Law Scholarship. It has been accepted for inclusion in Texas A\&M Journal of Property Law by an authorized editor of Texas A\&M Law Scholarship. For more information, please contact aretteen@law.tamu.edu. 


\title{
Equality and Closure: The Paradox of local Citizenship
}

\author{
Kenneth A. Stahl
}

In Bourgeois Utopias, a cultural history of suburbia in America, Robert Fishman states the fundamental paradox about the suburbs: "[H]ow can a form based on the principle of exclusion include everyone?" The promise of the American suburb was that every middleclass family would be able to own a home with a yard, but this egalitarian ideal was illusory because what made the suburbs appealing was precisely what it excluded, namely everything having to do with the city - its congestion, political corruption, and most importantly, its racial diversity. And so, as suburbia was mass-produced and made available with cheap low-interest loans to white middle-class families, racial minorities were rigidly excluded. ${ }^{2}$

Although several waves of demographic change have reshaped the suburbs over the generations, this paradox remains evident today. Suburbs are becoming more dense and more diverse as many minorities have migrated from "inner cities" toward first-ring suburbs, and immigrants have found welcoming enclaves in the suburbs. ${ }^{3}$ But while

DOI: https://doi.org/10.37419/JPL.V8.I1.3

'Bio: Kenneth Stahl is a Professor of Law and the director of the Environmental, Land Use, and Real Estate Law program at Chapman University Fowler School of Law. He is the author of Local Citizenship in a Global Age (Cambridge University Press 2020), which discusses how the nature of citizenship and the relationship between local and national governments have been transformed by globalization. Professor Stahl's scholarly works have been widely published in many journals. He is also a land use attorney who works to ensure that cities' land use policies comply with state and federal law, and a board member of People for Housing, Orange County, a chapter of the "Yes In My Backyard" movement that seeks to reform zoning laws to legalize the production of more housing.

1. Robert Fishman, Bourgeois Utopias: THE Rise AND FALl of Suburbia 15 (1987).

2. See Jessica Trounstine, Segregation by Design: Local Politics And INEQUALITY IN AMERICAN CITIES 5 (2018); RICHARD ROTHSTEIN, THE COLOR OF LAW: A ForgotTEN History OF How OUR GOVERNMENT SEGREGATED AMERICA 64-65 (2017); LIZABETH COHEN, A CONSUMERS' REPUBLIC: THE POLITICS OF MASS CONSUMPTION IN POSTWAR AMERICA 184-91, 200-04, 265-67, 286-89 (2003).

3. AUdrey Singer ET AL., TwENTY-FIRST CENTURY GATEWAYS: IMMIGRANT INCORPORATION IN SUBURBAN AMERICA 47-48 (2008); Margaret Crawford, Afterword to MAKING SUbURBIA: NEW HistORIES OF EVERYDAY AMERICA 382 (John 
suburbs have grown more diverse, they have also grown more segregated. High opportunity suburbs with plentiful jobs and good schools mandate low-density sprawl through zoning regulations, like minimum lot size and floor area requirements, parking mandates, and setbacks, that have the cumulative effect of making housing scarce and expensive. ${ }^{4}$ Only the very affluent or those lucky enough to have purchased a home years ago are welcome in these places. Racial minorities who, thanks to the earlier generation of suburban exclusion, have not had the opportunity to build the inter-generational wealth that is often a prerequisite to purchasing a home in the suburbs still find themselves locked out of the most desirable communities. ${ }^{5}$ The infrastructure of suburban communities, such as roads, sewers, and schools, are designed, perhaps deliberately, to completely collapse if the number of users increases by even a small amount, so these communities fiercely oppose any efforts to densify and permit more housing. Even modest attempts at densification are treated as calls to destroy suburban neighborhoods. ${ }^{6}$ But because our society has made a decision, undoubtedly questionable in retrospect, to treat suburban homeownership as the central tool for wealth building in this country, we cannot hope to meet our national aspirations for equality without opening up our suburbs to more housing. And so the question remains - how can a form based on the principle of exclusion include everyone?

This question is, in a manner of speaking, the central question explored in my book Local Citizenship in a Global Age, ${ }^{7}$ although I explore it in a slightly different way, through the prism of citizenship and particularly the idea of local citizenship. Like the suburb, citizenship has always been based on the idea of exclusion - citizens are defined in opposition to those who are not citizens. ${ }^{8}$ But especially in the

Archer et al. eds., Univ. of Minn. Press 2015); THE NEW AMERICAN SUBURB: POVERTY, RACE AND THE ECONOMIC CRISIS 74-75 (Katrin B. Anacker ed. 2015).

4. SANFORD IKEDA \& EMILY WASHINGTON, HOW LAND-USE REgULATION UNDERMINES AFFORDABLE HOUSING 4-5 (2015), https://www.mercatus.org/system/files/Ikeda-Land-Use-Regulation.pdf [https://perma.cc/5JB5-JNE3].

5. Id. at 5 .

6. In my home state of California, two bills to permit modest increases in density in residential neighborhoods were enacted in 2021 over a torrent of opposition from homeowners who complained that the bills would destroy residential neighborhoods. See, e.g., Conor Dougherty, After Years of Failure, California Lawmakers Pave the Way for More Housing, N.Y. TIMES (updated Sep. 20, 2021), https:/www.nytimes.com/2021/08/26/business/california-duplex-senate-bill-

9.html [https://perma.cc/AAX3-SNBR].

7. Kenneth A. Stahl, Local Citizenship in a Global Age 13-18 (2020).

8. Id. at $13-14$. 
liberal political tradition of the United States, we have simultaneously recoiled against the idea that we should treat some people less favorably than others because they are non-citizens. ${ }^{9}$ This paradox is especially prevalent at the local level. Citizenship was born in the city. ${ }^{10} \mathrm{~A}$ city, being by definition a place without borders, a place for the "being together of strangers," 11 arguably cannot function as a political entity unless it has some way of distinguishing members from foreigners, those with a genuine stake and attachment to the community from those whose interests are ephemeral or perhaps even antagonistic to those of the community. On the other hand, the very fact that the city is open and borderless means that the boundaries of "community" are constantly contested, and the distinction between strangers and citizens is constantly blurred. ${ }^{12}$

As my opening discussion of suburbia illustrates, the paradox of local citizenship often manifests in conflicts over the meaning and use of public space. ${ }^{13}$ When we refer to "public space," we do not generally mean space that is governmentally-owned, like "public housing" or "public utilities," but space that is accessible to the public. ${ }^{14}$ Ironically though, the "public" does not necessarily mean everyone. The nature and boundaries of the "public" are highly contested because they determine who is entitled to access public space, and, more broadly, who we consider to be part of our community of local citizens. ${ }^{15}$ In urban life, as I recount in Local Citizenship in a Global Age, access to public space has always been contested for this very reason. ${ }^{16}$ The struggles of marginalized groups to attain true citizenship were simultaneously struggles to attain access to public spaces. Mary Ryan's important history, Civic Wars, revealed that during a time when participation in local politics was being increasingly restricted to a privileged class, those who were shut out of formal political participation used public space to assert their difference and push for greater access to politics. ${ }^{17}$ Progressive reformers fought back by more decisively taking control of public space, segregating public space

9. See id. at 41 .

10. Id. at 40 .

11. IRIS MARION Young, Justice AND THE POLITICS OF DifFERENCE 237 (1990).

12. I discuss many historical examples of how cities managed their relationships with strangers in chapter 3, "A Short History of Local Citizenship." See STAHL, supra note 7 , at $69-81$.

13. Id. at $168-70$.

14. See id. at 168 .

15. Id. at 171 .

16. Id. at $171-72$.

17. See MARY P. Ryan, CiviC WARS 259-78 (1997). 
with formal and informal zoning practices and tasking newly professionalized police forces to monitor those spaces. ${ }^{18}$

While cities have often been defined by these sorts of struggles over public space, the question was, in a way, ultimately resolved by the suburbs. Rather than constantly contesting who gets to access public space, suburbs essentially privatize that space by rigidly controlling access to it and transforming its users from contestants in a battle over public space into consumers of municipal services. ${ }^{19}$ In recent years, however, a "Yes in My Backyard" movement has emerged that seeks to open up the suburbs by demanding zoning reforms that would make suburban homes available to a wider class of consumers. ${ }^{20}$

Both the initial movement toward suburban closure and the more recent movement to open up the suburbs stem from what the book calls a "liberal" view of citizenship. ${ }^{21}$ The book counterposes two different ways of thinking about citizenship: liberal and ethno-nationalist. While ethno-nationalism generally sees the state as the outward expression and container of a discrete nation with organic ties to the territory it occupies, liberalism sees the state as a construct designed to preserve individual rights and market freedom. ${ }^{22}$ As such, where ethno-nationalism seeks to define the class of members based on ascriptive criteria such as race or ethnicity, liberalism defines it in terms of money and mobility. ${ }^{23}$ Anyone who has the means to establish residence in a place can become a citizen of that place under the liberal view. ${ }^{24}$ As a descriptive matter, I argue that liberal ideas of citizenship have largely prevailed at the local level because localities' open borders and dependence on commerce lead almost inexorably to an idea of membership that is less bound to nationality and more to market principles. $^{25}$ I demonstrate that many localities, even deeply

18. See id. at 183-222; STAHL, supra note 7, at 196-201; Regina Austin, "Not Just for the Fun of It!'”: Governmental Restraints on Black Leisure, Social Inequality, and the Privatization of Public Space, 71 S. CAL. L. REV. 667, 681-84, 697 (1998) (discussing the discriminatory regulation of public spaces, transportation, and transportation infrastructure that effectively prevents blacks from occupying public white spaces).

19. See Austin, supra note 18, at 694-95.

20. Kenneth A. Stahl, "Yes in My Backyard": Can a New Pro-Housing Movement Overcome the Power of NIMBYs?, 41 ZONING \& PLAN. L. REP., Mar. 2018, at $1-3$, https://papers.ssrn.com/sol3/papers.cfm?abstract_id=3087508 [https://perma.cc/3WK6-LP9U].

21. Id. at 3.

22. See STAHL, supra note 7, at 21-39.

23. See id. at 201.

24. Id. at 191-92.

25. Id. at $168-69$. 
conservative ones, have adopted different types of policies to accommodate immigrants as members of the community, even if only a few were willing to openly proclaim themselves "sanctuary cities." 26 But ironically, if local citizenship holds the promise of liberating people from the divisions of ethnicity and nationality, it does so largely by substituting in its place the division of money and mobility. Exclusionary zoning laws, for example, are deliberately designed so that only the most affluent can afford to live in the highest-opportunity places. ${ }^{27}$ Cosmopolitan cities like San Francisco tout their openness to immigrants regardless of immigration status but maintain zoning regulations that are so restrictive only the very wealthiest people can actually afford to live there.

As I argue in the book, this new stratification along the lines of money and mobility, while consistent with market liberalism in a certain sense, is also a betrayal of liberalism's aspiration for equality. ${ }^{28}$ Market liberalism is properly understood as part and parcel of a broader movement to make society more equal by reducing the traditional lines of stratification like land ownership or nationality. ${ }^{29}$ The demands coming from the "Yes in My Backyard" movement that localities end their exclusionary zoning policies and make room for newcomers are therefore also drawing on liberal principles. Hence, we see again the paradox of local citizenship - how can a principle based on exclusion include everyone?

In their insightful responses to my book, Professors Eric Claeys and Sarah Schindler each take on a slightly different component of this paradox. Professor Claeys incisively questions my premise that liberal citizenship is distinct from ethno-nationalism, arguing that, in fact, liberalism requires closure on an ascriptive basis in order to achieve its ideals of equality. ${ }^{30}$ Professor Schindler intriguingly explores the paradoxical idea discussed in my book that "the 'public' is defined by who is excluded," and asks the question, "whether we can expand our ideas of who is (and should be) included in the public without losing a sense of tight-knit belonging that seems to be psychologically

26. See id. at 52, 110-11, 119 (discussing research of ABIGAIL FISHER WILLIAMSON, WELCOMING NEW AMERICANS? LOCAL GOVERNMENTS AND IMMIGRANT INCORPORATION (2018)).

27. Id. at 157.

28. Id. at $168-69$.

29. Id. at 111.

30. Eric R. Claeys, Liberalism, Patriotism, and Cosmopolitanism in Local Citizenship in a Global Age, 8 TEX. A\&M J. PROP. L. 1 (2021). 
necessary for some people." 31 In my view, both are asking the same question - how does a theory of citizenship balance equality with closure?

Claeys's remarks focus on my book's implications for immigration policy. ${ }^{32}$ In the book, I argue that the United States' legal and political tradition has largely balanced between equality and closure through a form of "citizenship federalism" in which the liberal view of citizenship largely prevailed at the local level while federal citizenship remained defined in ethno-nationalist terms. ${ }^{33}$ Thus, for example, while anyone with the means to establish residence can become a citizen of a locality, one can only obtain citizenship at the national level through ascriptive means, such as birth or naturalization. ${ }^{34}$ I further argue that the root cause of our manifold political crises today is that the liberal view of citizenship has begun to take hold at the national level as globalization has given immigrants the ability to "vote with their feet," and nation-states have felt pressure to loosen immigration policies and grant the benefits of citizenship on the basis of residence rather than identity. ${ }^{35}$

Claeys, on the other hand, argues that liberalism does not necessarily imply a loosening of immigration policy, but, in fact, can accommodate and perhaps presupposes ethno-nationalist limits on immigration. ${ }^{36}$ In his view, citizenship can be both liberal and patriotic. ${ }^{37}$ Though a liberal society is committed to individual rights and thus sees any kind of association warily, the bonds of nationhood are necessary to create the "affection and trust" that "help secure individual rights." 38 He correctly observes that "patriotism can make a people more secure in natural rights associated with personal safety and collective security," and it is "reasonable" for a nation's people "to expect all citizens to be loyal enough to the government and its projects to contribute to their defense." 39 "A liberal community needs to be communitarian in a few specific dimensions - most of all, in socializing

31. Sarah Schindler, Questions of Citizenship and the Nature of "The Public," 8 TEX. A\&M J. PROP. L. 19, 27 (2021).

32. See Claeys, supra note 30.

33. STAHL, supra note 7 , at 95.

34. Id. at $40-68$.

35. Id. at $148-54$.

36. Claeys, supra note 30 , at 3.

37. Id. at 12 .

38. Id.

39. Id. at 13 . 
citizens to have the social and political virtues expected in a system of republican government." 40

I agree with each of these points, but I have a hard time seeing them as good-faith liberal justifications for the current nativist strain of opposition to immigration. If critics were serious about "socializing citizens to have the social and political virtues expected in a system of republican government," then presumably they would advocate strengthening our system of public education - the best mechanism for "socializing" children that our system of government has ever devised - to ensure that every child in the United States has access to a quality public education. ${ }^{41}$ The very idea of free, compulsory education emerged during the Progressive Era as a liberal-nationalist mechanism for ensuring the assimilation of immigrants. Public education was one of many public services, including public parks and even sanitation, perceived as unifying a diverse populace and providing them with a basis for civic pride. ${ }^{42}$ Public education has long been considered one of the pillars of liberal citizenship for just this reason, an idea echoed both by scholars like T.H. Marshall as well as the U.S. Supreme Court. ${ }^{43}$ Claeys himself acknowledges the critical role of public education in liberal thinking. ${ }^{44} \mathrm{He}$ observes that a just political community should be republican in maintaining "public morals . . . inculcat[ing] respect for equality and natural rights." 45 And how is such "inculcation" to happen but through a process of public education? As Claeys notes in a trenchant discussion of John Locke, Locke presumed that the public would be broadly educated through "a sound program of liberal ethical and political philosophy ...."46

Instead, ever since California's Proposition 187, often seen as the founding moment of our current strain of anti-immigrant nativism in the United States, ethno-nationalists have consistently sought to prevent immigrants from accessing public benefits, such as public

40. Id. at 14 .

41. Id.

42. See STAHL, supra note 7, at 129-30 (citing Gerald E. Frug, City Services, 73 N.Y.U. L. REV. 23, 86-87 (1998)).

43. Id. at 109, 113-14; T. H. MARSHALl, Citizenship and Social Class, in CLASS, CitizenshiP, AND Social DEvelopMent 72 (1964); Plyler v. Doe, 457 U.S. 202, 205, 208-09 (1982) (holding that the state could not withhold public education from unauthorized immigrant children because education is "the foundation of good citizenship").

44. Claeys, supra note 30 , at 7.

45. Id.

46. Eric R. Claeys, The Private Society and the Liberal Public Good in John Locke's Thought, 25 SOC. PHIL. \& POL'Y 201, 230-31 (2008). 
education, precisely because it would provide them with the essential tools of citizenship. ${ }^{47}$ It is clear that what is at the root of immigration opposition is not liberal concerns about the proper socialization of immigrants but ethno-nationalist concerns about the diminution of national identity and cohesion as a result of increasing diversity. ${ }^{48}$ As I describe in the book, the core of ethno-nationalism is the desire to create a firm boundary between citizens and non-citizens, a boundary that is eroded when non-citizens are given access to benefits like public education. ${ }^{49}$

I concede that the book treats this concern about boundary-drawing with some disdain because, as I elaborate a bit later, it relies on scapegoating vulnerable and politically marginalized groups to attain the ephemeral and ultimately illusory benefit of in-group cohesion. ${ }^{50}$ With that said, the book attempts to treat ethno-nationalist sentiments with some sensitivity, observing that liberalism's openness may create a psychological need for a mechanism for maintaining in-group homogeneity. ${ }^{51}$ As I argue in the book, the liberal aspiration for equality can be, and in our society has been, combined with an ethno-nationalist need for unity by creating a liberal-nationalist ideal in which individuals enjoy liberty and equality within the context of closure. ${ }^{52}$ As I quote Yael Tamir, the liberal-nationalist conception of the citizen "portrays an autonomous person who can reflect on, evaluate, and choose his conception of the good, his ends, and his cultural and national affiliations, but is capable of such choices because he is situated in a particular social and cultural environment that offers him evaluative criteria." $" 53$

Nevertheless, as I argue, the liberal-nationalist synthesis creates some tensions between the liberal norm of equality and the nationalist idea of closure. ${ }^{54}$ Schindler nicely summarizes this debate by asking "whether we can expand our ideas of who is (and should be) included in the public without losing a sense of tight-knit belonging that seems

47. Tyler Larsen, Proposition 187: California's Fear of Immigration 5 (Spring 2017) (B.A. thesis, Western Oregon University) (on file with the Hamersly Library, Western Oregon University) https://digitalcommons.wou.edu/his/63 [https://perma.cc/L4P6-ZEQE].

48. Id. at 8 .

49. See STAHL, supra note 7, at 6-8, 153-54 (on ethno-nationalist desire to "firm up the distinction between citizens and noncitizens").

50. Id. at 168-69.

51. Id. at 204-06.

52. Id. at 36-37.

53. Id. at 37 (quoting YAEL TAMIR, LIBERAL NATIONALISM 33 (1993)).

54. Id. at 38 . 
to be psychologically necessary for some people." ${ }^{, 55}$ This is, again, a version of the opening question: how can a form based on exclusion include everyone?

These questions pervade Schindler's thoughts on the book, especially in her musings on the search for "authenticity" in urban life and the meaning of authenticity itself. ${ }^{56}$ Conflicts over access to public space frequently turn on questions of how the space ought to be used and, more importantly, who should have the right to use it. The nebulous concept of "authenticity" is often deployed as a framework to draw such lines. What is an authentic use of the space? Who is an authentic user? ${ }^{57}$ Authenticity comes up especially often in debates surrounding gentrification, a similarly nebulous term generally referring to the phenomenon whereby places that have been traditionally occupied by disadvantaged communities, usually communities of color, are repurposed for white middle-class consumption. ${ }^{58}$ In this context, "authentic" means a use of the space that has a deep, respectful, and organic relationship with the space's historical function and purpose and the community that historically occupied it. Such an authentic relationship is often seen as non-commercial or anti-capitalist in opposition to the inauthenticity of middle-class commercial consumption that often characterizes gentrification. As Schindler notes, we are wary of "commerce corrupting place." 59

But the search for authenticity is ominous. The idea that there is a true or authentic public with the right to use and occupy particular spaces necessarily implies that those who are inauthentic should be excluded from the space. The "public" that the space is designed to serve is defined by who is excluded from the public - indeed, a true public cannot emerge without constantly policing the boundaries of the public and rigidly excluding those who are inauthentic. In fact, the discourse and politics of gentrification have often focused less on preserving the authentic local culture than on policing and excluding inauthentic users. Most of the energy in anti-gentrification advocacy has

55. Schindler, supra note 31 , at 19-27.

56. Id. at 22-23.

57. See generally Sarah Schindler, The "Publicization" of Private Space, 103 IOWA L. REV. 1093, 1138-40 (2018).

58. Many works explore the connections between gentrification and the search for authenticity. See, e.g., SHARON ZUKIN, NAKED CITY: THE DEATH AND LIFE OF Authentic URban Places (2010); JAPONICA BROWN-SARACINO, A NeIGHBORHOOD THAT NEVER CHANGES: GENTRIFICATION, SOCIAL PRESERVATION, AND THE SEARCH FOR AUTHENTICITY (2009).

59. Schindler, supra note 31 , at 25. 
focused on blocking new "luxury" condos and apartments despite the weight of evidence demonstrating that such housing does not advance displacement and is, in fact, more likely to reduce it. ${ }^{60}$ The hostility toward new market housing, notwithstanding this body of evidence, results from a kind of nativist fear of outsiders invading and disrupting the organic community. ${ }^{61}$ As Zukin acknowledges, "[t]hough we think authenticity refers to a neighborhood's innate qualities, it really expresses our own anxieties about how places change."62

In this regard, the search for authenticity and the desire to purge commerce from "authentic" spaces is a manifestation of the same nativist tendencies now dominating the debate over immigration. Just as nativists derive the unity of nationhood by othering those who are not part of the nation, the notion of authenticity exists only in relation and in opposition to those deemed inauthentic. ${ }^{63}$ Scapegoating visible and often politically marginalized groups becomes essential to maintaining in-group cohesion. ${ }^{64}$

What's worse is that both efforts - to preserve authenticity and to create national unity - are doomed to fail because places, as well as nations, are not stable things but constantly in flux. As I describe in the book, globalization is inexorably breaking down borders, both at the national and the local level. ${ }^{65}$ Change is constantly knocking at the door of our communities, and the fantasy that we can control it becomes dangerous once we realize we cannot because the futile search for authenticity and closure causes us to draw the boundary of the "authentic" community tighter and tighter. Where ethno-nationalists in this country began by demonizing "illegal" immigrants, they quickly turned their sights on legal immigrants, Muslim Americans, black Americans, journalists, and then pretty much everyone living in an urban area or a "blue" state who are constantly denigrated as being not "real" Americans. 66

60. See STAHL, supra note 7, at 187-88; Kenneth A. Stahl, Incorporating Transportation Topics into the Land Use Curriculum, 106 IOWA L. REV. 2451, 2489-91 (2021).

61. See STAHL, supra note 7 , at $187-88$.

62. ZUKIN, supra note 58, at 220.

63. See STAHL, supra note 7, at 153-54.

64. Id.

65. See STAHL, supra note 7.

66. See id. at 3-4, 7-8, 153-54, 189. 
Likewise, authenticity in urban life is forever elusive, requiring ever more rigid policing of what is and what is not authentic. ${ }^{67}$ As Schindler writes:

[T] he question of what is authentic - and who gets to decide what is authentic-is itself somewhat problematic. One problem with authenticity as it relates to public space is that spaces that are perceived as authentic are sought after; they are thus colonized and gentrified, which often leads to a perceived lack of authenticity. ${ }^{68}$

Ironically, those who are most concerned with preserving the community's authenticity are those who are most complicit in destroying it. The most militant guardians against gentrification and in favor of preserving authenticity are the first-wave gentrifiers trying to prevent the second wave. They are assuaging their guilt about "Columbusing" in a neighborhood by styling themselves the "curators" of an authenticity they know they themselves do not possess. ${ }^{69}$ The idea of a neighborhood that never changes is a search for an artificial authenticity that never existed, and if it ever did, the very search for it becomes complicit in destroying it.

In short, the sort of closure that ethno-nationalists seek is unattainable in a liberal democracy. We have no choice but to expand our sense of "community" and jettison the futile search for authenticity. Liberalism's focus on equality and its rejection of nativist borders offer us a pathway toward that future. There is little doubt that the liberal idea of "citizen-consumers" has, on the whole, made our society more inclusive. ${ }^{70}$ Lizabeth Cohen demonstrates that during the postwar period, as citizenship increasingly merged with consumerism, marginalized groups like women and blacks were able to use their power as consumers to obtain political rights they had previously been denied. ${ }^{71}$ They have succeeded so well, in fact, that multiculturalism is actually declining and more groups that were once distinct markets, especially Hispanics, are now assimilating toward the lifestyle traditionally associated with the white middle class. ${ }^{72}$ Even the suburbs, the dark heart

67. See id. at 189.

68. Schindler, supra note 31 , at 23.

69. JOHN JOE SCHLICHTMAN ET AL., GENTRIFIER 166-67 (2017).

70. See Anke Ortlepp, Jim Crow Terminals: The Desegregation of AMERICAN AIRPORTS 2-3 (2017) (discussing how the era of air travel ushered in a new "mobile integrationist nationwide culture" in which blacks had agency as "citizen-consumers").

71. COHEN, supra note 2, at 31-53, 75-100.

72. STAHL, supra note 7 , at 231. 
of societal exclusion, have become far more welcoming and diverse than the cities that were once defined by their openness to strangers. As Margaret Crawford writes: "[D]ifference may actually be the defining characteristic of suburbia, rather than the sameness consistently attributed to it. In fact, currently, in an inversion of conventional wisdom, cities are becoming more homogenous while suburbs grow more diverse." 73

At the same time, the suburbs remain a contradiction. Despite their increasing diversity, suburbs are as segregated as ever with affluent suburban residents using the liberal language of rights and markets to justify their exclusivity. But, as noted earlier on, the grassroots "Yes in My Backyard" movement has recently begun appropriating that same liberal framework to insist that suburbs open their doors for new neighbors. ${ }^{74}$ Perhaps that is why the suburbs have become an increasingly salient battlefront in the societal quest for equality, and why the battle is primarily over the future of liberalism rather than tired concepts like "authenticity." 75

Admittedly, though, liberalism has its limits as a basis for citizenship. Equality is not a framework for determining membership, and, as I have argued before, "citizen" is "not a meaningful category unless there is also a class of people who are not citizens." 76 While some have endorsed "world" or "global" citizenship, they are not really proposing a theory of membership or community, but a theory of justice. ${ }^{77}$ Robert Cover argued that universalist values like justice are weak, "system-maintaining forces," that exist to protect "worlds of strong normative meaning," but cannot create or nourish them. ${ }^{78}$ Only shared identity has the power to create such worlds of normative meaning. But we cannot assume that identity and community are fixed quantities immune to change. As I have argued:

The crises of our present political moment - the nativist opposition to immigration at the national level and massive suburban resistance to zoning reform at the local level - both stem from the same anxious sensation that change is at the

73. Crawford, supra note 3 , at 382.

74. Stahl, supra note 20 , at 1 .

75. Id. at 5.

76. Kenneth Stahl, Cities vs States: Should Urban Citizenship be Emancipated from Nationality?, GLOB. CITIZENSHIP OBSERVATORY (Dec. 16, 2019), https://globalcit.eu/cities-vs-states-should-urban-citizenship-be-emancipated-from-nationality/22/ [https://perma.cc/ED8A-MCJV].

77. Id. (quoting MARTHA C. NUSSBAUM, FOR LOVE OF COUNTRY? (2002)).

78. Id. (quoting Robert Cover, Foreword: Nomos and Narrative, 97 HARV. L. REV. 1, 12 (1983)). 
door. Indeed, in our age of globalisation, there is no way to turn back the tide of increasing population mobility. ${ }^{79}$

According to Jerry Frug, "giving up the idea that the world can be purified or controlled" can reduce one's anxiety and enable one to live a fuller life as one develops "a confidence that one won't be overwhelmed by complexity or disorder, a feeling that one can live with, even learn to enjoy, otherness." 80 That confidence to reject a static conception of community and embrace dynamism and change is, ultimately, what local citizenship can offer us in a global age. ${ }^{81}$

79. Id.

80. Id. (quoting Gerald FRUG, City MAKING: BuIlding COMMUNities WITHOUT BUILDING WALLS 120-21 (1999)).

81. Id. 